\title{
NON-JURISDICTIONAL FORMS OF PATENT RIGHTS PROTECTION IN THE RUSSIAN FEDERATION
}

\author{
Ruslan B. Sitdikov ${ }^{1}$ \\ Ravil M. Sadykov²
}

\begin{abstract}
This article discusses the features of the implementation of nonjurisdictional forms of protection of civil rights (self-defense, claims, mediation) in relation to patent infringements in the Russian Federation. It is noted that the self-defense of patent rights by classical means in non-contractual legal relations is limited due to the peculiarities of the legal nature of the objects of patent rights, namely because of their intangible nature, the general availability of information about them, the presence of state registration, but it is possible to use special means of self-defense: software and hardware, introduction trade secrets, optimization of patenting and legal

Protection of Competition regarding the assessment of good faith / unfairness of the distribution by the patent holder of warnings about the alleged violation of his rights and apply the approach according to which: the patent holder has the right to protect his exclusive right, and also in case of threat of negative consequences from third parties, to disseminate information about the alleged, in his opinion, a violation of his rights, including against the alleged offender, as well as other persons, including buyers / p purchasers of goods, works, services of the patent holder or the alleged infringer, which in itself is not an act of unfair competition.
\end{abstract} protection strategies as know-how. It is concluded that it is necessary to specify the provisions of Articles 1252 of the Civil Code of the Russian Federation and Articles 14.1. - 14.3. Federal Law on the
Keywords: protection of patent rights, non-jurisdictional forms, self-defense, claim, warning, mediation.

\footnotetext{
1 Kazan Federal University, Law Faculty. e-mail: ruslan.sitdikov@gmail.com. Tel.: 89172572445.

${ }^{2}$ Kazan Federal University, Law Faculty. e-mail: ruslan.sitdikov@gmail.com. Tel.: 89172572445.
} 


\section{Sireitere}

1. Introduction

For patent rights, as well as for other intellectual rights [1], a complete set of forms of their protection is characteristic [2]:

- jurisdictional forms, which include judicial protection (including in arbitration courts), protection in other state and authorized bodies (industry body (Rospatent), law enforcement agencies, notary public and others),

- non-jurisdictional forms (claim, self-defense, mediation and others).

In this article, we consider the features of the implementation of nonjurisdictional forms of patent protection.

\section{Methods}

The methodological basis of the work was based on the application of the general principles of scientific knowledge (objectivity, comprehensiveness, completeness of research) and general scientific methods of cognition (analysis, synthesis, approach, deduction, etc.) a system of methods and techniques for studying legal phenomena. In the course of the study, special (general theory of systems) and private-scientific methods
Periódico do Núcleo de Estudos e Pesquisas sobre Gênero e Direito Centro de Ciências Jurídicas - Universidade Federal da Paraíba V. 8 - No 06 - Ano 2019 - Special Edition (comparative-legal, formal-legal) were applied.

\section{Results And Discussion}

Despite the fact that the institution of self-defense of civil rights has long been known in civil law, its definition and interpretation of this concept, as well as its application by the courts, is still not uniform. The Civil Code of the Russian Federation does not disclose this concept. The Resolution of the Plenum of the Supreme Court of the Russian Federation of June 23, 2015 N 25 "On the application by the courts of certain provisions of section I of part one of the Civil Code of the Russian Federation" although gives some examples (the impact of a person on his own or in his legal possession property, necessary defense, extreme need), but also does not provide a complete definition and an exhaustive list of cases / types [3].

In the legal literature [4] there are also the following actions that can be classified as self-defense of civil law:

- unilateral actions in the contractual relationship (unilateral termination of the contract, suspension or termination of obligations, 
withholding, etc.). They are also called operational measures.

- unilateral actions aimed at preventing violation (expelling people from an immovable object, removing obstacles to using the thing on their own, including using physical force, removing and detaining other people's animals from the territory, removing harmful and dangerous objects, removing illegal advertising structures, for example, from the building of the owner, independent withdrawal of the thing by the owner, who has lost its possession, etc.). In the literature, these actions are also called "self-help".

The self-defense of patent rights due to the special legal nature of their objects, as rightly noted in the literature, is limited to a certain framework [5]. Firstly, since the emergence, termination and transfer of rights is carried out through state registration. Secondly, the objects of patent rights are intangible, and information about them is published openly.

Therefore, many of the above "classic" means of self-defense from the group of non-contractual relations are not applicable in relation to patent rights. As you know, copyright law uses
165 technical means of copyright protection in accordance with Article 1299 of the Civil Code of the Russian Federation, which are used as "any technologies, technical devices or their components that control access to a work, prevent or limit the implementation of actions that are not authorized by the author or other copyright holder in relation to the work. "We believe that with respect to patent rights, sometimes similar technologies can also be applied. For example, those devices that are accompanied or contain certain software tools (built-in chips, positioning devices (GPS, GLONASS, etc.), communication with a cloud server and management through it, etc.), in some cases may be technically limited at the program level in use by the will of the copyright holder, and remotely. It can also serve as assistance to the copyright holder to identify the volume of product turnover on the market for subsequent filing of a claim and determining the amount of losses / compensation.

Another means of self-defense is the introduction of a trade secret regime and the exclusion of unauthorized persons from access to information about the invention until the patent is granted. 
Choosing the right patenting and legal protection strategy as knowhow can also be seen as a means of selfdefense. It is known that many companies when patenting do not disclose all the nuances of the effective use of the invention in its formula, leaving a lot of secrets and know-how in such a way that another person could not carry out the production on their own, even if they got acquainted with the contents of the patent [6].

However, it should be noted that, despite the above rather effective measures in some cases, more often the means of self-defense in relation to patent rights objectively turn out to be inapplicable and / or ineffective.

In judicial practice, there is a broader interpretation of the concept of self-defense, referring to it and the possibility of filming in open places for a general visit while collecting evidence of a violation of patent (as well as other intellectual rights), and recognizing such actions as legal and relevant, including part 2 of article 45 of the Constitution of the Russian Federation, and the evidence collected is admissible.

\section{Claim.}

166

The next non-jurisdictional form of patent protection is to file a claim against the alleged infringer. For some disputes (property character) about violation of the exclusive right, including patent law, considered in the arbitration courts of the Russian Federation, article 1252 of the Civil Code establishes a mandatory pre-trial claim procedure.

A fairly common occurrence in practice is also the direction by the patent holder before or during the appeal to the court about the violation of his exclusive right of warning letters to large buyers or other partners the alleged infringer of the alleged patent infringement. Such actions cause a double assessment [7]. On the one hand, if such a warning is compiled correctly, it does not contain inaccurate information (for example, the letter sets out only information about the presence of a patent, about the existence of a litigation or just an opinion, and not an allegation, about a possible violation of patent rights, about the consequences for the addressee subsequent recognition by the court of the fact of patent infringement, withdrawal of counterfeit products from circulation, etc.), such an action, in our opinion, can be considered an element of legal self-defense. 
Moreover, it is even correct and conscientious that the patent holder warned potential counterparties in advance about the possible negative consequences of the upcoming conflict for them, the dangers of acquiring counterfeit products, etc. On the other hand, it is natural that sending out even the correct such warning letters discredits the reputation, including business, of the defendant. Some of the contractors, simply out of caution, may partially or completely terminate or suspend cooperation with the alleged offender (for example, temporarily stop purchasing goods from him or ordering work / services for him) and even, with a limited number of offers on the market, start or increase purchases from patent holder who sent out such letters. In the event that in a subsequent court it is established that there are no violations of the rights of the patent holder and the groundlessness of his claims, the question arises whether such actions are an act of unfair competition?

Russian legislation on the protection of competition does not give a direct answer to this question and does not contain special provisions regarding the legal qualification of mailing warning letters about infringement of patent and other intellectual rights, but contains only general provisions of articles 14.1. (on discrediting), 14.2 (on misrepresentation), 14.3. (about incorrect comparison). However, their content and explanations do not allow us to clearly understand whether such actions are an act of unfair competition or not.

This issue has been given attention in the legal literature, but not so much [8]. In it, including foreign experience is investigated. So, it is noted that in many developed countries. A noteworthy example is the US legislation, where the usual right to send warning letters to the copyright holder, both to the alleged offender and to his customers, is legal [9]. However, if this newsletter contains an inaccurate, libelous or derogatory character, then it qualifies as a special case of "disparagement".

In the case of objects of patent rights, the situation is more complicated than with other objects of intellectual rights, because the presence or absence of patent infringement is often nonobvious, moreover, it is controversial and difficult even for specialists in the 
relevant field of technology. In many legal disputes over violation of the exclusive right to invention, commissions, repeated and additional forensic examinations are appointed, in many countries such disputes are examined in specialized patent courts with a collegiate composition of judges with not only legal, but also special knowledge, as well as specialists.

It should be noted that the dispatch of warning letters today is a widespread and very effective, but at the same time dangerous form of patent protection, often more effective than judicial or administrative. It happens that even a victory in a court case for a patent holder does not bring such a tangible effect (due to the length of the litigation or insolvency of the defendant) as from sending letters, the reaction of buyers to which occurs almost immediately. But the same factor is sometimes used in bad faith [10].

In connection with the foregoing, we believe that there is a certain need for concretization of the provisions of Articles 1252 of the Civil Code of the Russian Federation and Articles 14.1. - 14.3. Federal Law on the Protection of Competition regarding the
168

criteria of good faith / unfair distribution of information by the patent holder (or the holder of the exclusive right to other objects) about the alleged violation of his rights. The following approach is proposed: for the purpose of protecting his exclusive right, and also in the event of a threat of negative consequences from third parties, the patent holder is entitled to disseminate information about the alleged, in his opinion, violation of his rights, including to the alleged offender, as well as other persons, including buyers / purchasers of goods, works, services of the patent holder or the alleged infringer, which in itself is not an act of unfair competition.

\section{Mediation.}

Non-jurisdictional form of protection of civil rights can also include mediation. The Chairperson of the Intellectual Property Rights Court, Professor L.A. Novoselova, on April 25, 2018, as part of the International Forum "Intellectual 21st Century Property", the Chamber of Commerce and Industry of Russia noted the relatively high media stability of intellectual property disputes due to the relatively high percentage of 
settlement agreements concluded in such disputes (about 10\%) [11].

\section{Summary}

Thus, based on the foregoing on non-jurisdictional forms of patent protection, the following conclusions can be drawn:

1) Patent rights can be protected in the following non-jurisdictional forms: by self-defense, by sending a complaint to the infringer, by sending warnings to other persons, through mediation.

2) When protecting patent rights, it is possible to use special means of self-defense: software and hardware, the introduction of a trade secret regime, optimization of the patenting strategy and legal protection as know-how.

3) It is proposed to specify the provisions of Articles 1252 of the Civil Code of the Russian Federation and Articles 14.1. - 14.3. Federal Law on the Protection of Competition regarding the assessment of good faith / unfairness of the distribution by the patent holder of warnings about the alleged violation of his rights and apply the approach according to which: the patent holder has the right to protect his exclusive right,
169

and also in case of threat of negative consequences from third parties, to disseminate information about the alleged, in his opinion, a violation of his rights, including against the alleged offender, as well as other persons, including buyers / p purchasers of goods, works, services of the patent holder or the alleged infringer, which in itself is not an act of unfair competition.

\section{Conclusions}

As you can see, nonjurisdictional forms of protection of patent rights by classical means are limited due to the peculiarities of the legal nature of the objects of patent rights, namely because of their intangible nature, the general availability of information about them, the presence of state registration. At the same time, in those situations and conflicts where they are nevertheless applicable, they often turn out to be more effective than jurisdictional forms of protection, since more quickly and at a lower cost to the copyright holder they result in and / or settlement of the conflict.

\section{Acknowledgements}


The work is performed according to the Russian Government Program of Competitive Growth of Kazan Federal University.

\section{Bibliography}

Sitdikova R., Sitdikov R. Violated Copyright protection in the Russian Federatijn // Mediterranean Journal of Social Scienses MCSER Publishinq Rome-Italy, 2014, P.471-476

Valeev D.K., Baranov S.Y. The reform of the civil procedural legislation: world trends // Life Science Journal. 2014. No. 11 (12p). P. 728-731

Resolution of the Plenum of the Supreme Court of the Russian Federation of June 23, 2015 N 25 "On the application by courts of certain provisions of section I of part one of the Civil Code of the Russian Federation" // Bulletin of the Supreme Court of the Russian Federation, N 8, August, 2015

Yuzhanin N.V. Self-defense of civil rights: theory issues // Lawyer. 2015. N 19. P. 17 - 22. ATP "Consultant Plus".
C. M. Correa, Trade Related Aspects of Intellectual Property Rights. A Commentary on the TRIPS Agreement (Oxford University Press, New York, 2007)

S. Budylin and Y. Osipova, 'Total Upgrade: Intellectual Property Law Reform in Russia', Columbia Journal of East European Law, Legislative Development (2007).

WIPO Intellectual Property Handbook: Policy, Law and Use. 2001. Geneva.

Eremenko V.I. Issues of unfair competition in the framework of the "fourth antitrust package" // Competition law. 2016. N 1. P. 3 - 12. ATP "Consultant Plus"

Sannikova L. V., Kharitonova Yu. S. Protection of Patent Holders' Rights under a Conflict of Drug Patents. Perm University Herald. Juridical Sciences. 2019. Issue 1. P. 121-145. DOI: 10.17072 / 1995-4190-2019-43-121-145

Competition and Consumer Privacy in the Cyberspace Market Klien, Joseph A; Rao, PM; Dalvi, Manoj. JIPR Vol.23 (2- 
Periódico do Núcleo de Estudos e Pesquisas sobre Gênero e Direito Centro de Ciências Jurídicas - Universidade Federal da Paraíba V. 8 - No 06 - Ano 2019 - Special Edition ISSN | 2179-7137 | http://periodicos.ufpb.br/ojs2/index.php/ged/index

3) [March-May 2018]. 70-85

http://nopr.niscair.res.in/handle/123456

$789 / 45336$

Mediation in the field of intellectual

property // URL:

http://mediator33.ru/2018/04/26/mediac

iya-v-sfere-intellektualnoj-

sobstvennosti/. Date 05.16.2019 